\title{
Companies and responsible innovation: toward a long-term success
}

\section{Opinion}

Based on our knowledge and what we have learned, if a company is having a short-term success it does not ensure the long-term success sustainability nor that it can overcome the problems that may constitute obstacles facing the company prosperity. For instance, the non-ethics of the profession, the non-responsibility of the workers and managers of the company, budget mismanagement and the economic downturns and workflow can all lead to the loss of the company credibility and reputation in the market which leads to the downfall of a prosperous business. Development and innovation are essence doctrines for the business. Nowadays, the big dilemma is that many of the companies are competing to innovate new products, especially the small firms, they are so focusing in the day-to-day process of the trade, but they do not take the time to develop some strategies and plans for the future which is important to keep the innovation competitiveness within the industry which would guarantee the long-term success. To ensure such long-term success, the company managers and the staff must be highly ethical and have the sense of responsibility in their work as well as the development process of the products.

Jack Stilgoe and others described the concept of responsible research and innovation (RRI) as a "Responsible innovation means taking care of the future through collective stewardship of science and innovation in the present", 1,2 because the RRI is the main engine that leads the company to gain confidence and raise its credibility within the market, which drives it to maintain a prestigious position and keep its success and prosperity. Secondly the company managers should do an assessment and examination of their business including assessing the past and imagining the future, in order to have a brief and an overview about what the company has achieved and what the company needs to do to be more innovative and success to guarantee that it has the trend to maintain its successful status for the coming years. After doing the past assessment and after knowing the wrong issues and the missteps which can include poor marketing, capabilities shortage and qualifications, lack of research and development offerings, the high pricing of the products which makes that people cannot afford those innovated products, business operations mistakes and finances misusing. Company managers should take all these factors into consideration and must plan changes and ameliorations accordingly. George Santayana said: "Those who cannot remember the past are condemned to repeat it" ${ }^{\prime \prime}$ and repeating the same methods and expecting different results is an illogical approach, if things does not work, just do more and harder and sometimes persistent and intensified work can bring new satisfactory results.

Albert Einstein wants to make us understand that if something does not work, we should do it differently. The managers should ask themselves several questions for instance: What are the company strength and weakness points? What are the operations we did and that have contributed to the company success? What are the operations that have negatively affected the company? What are the major mistakes the company did? What are the solutions to correct them? All these questions are important because this "survey" must involve each and every part of the company business, otherwise the company
Volume 6 Issue 4 - 2017

\author{
Kadour Ghanemi,' Shuangsheng Yan ${ }^{1,2}$ \\ 'Department of Business Management, China Pharmaceutical \\ University, China \\ ${ }^{2}$ Department of Social Science, China Pharmaceutical University, \\ China
}

Correspondence: Shuangsheng Yan, Associate Professor, Director, The Philosophy of Teaching and Research Office, Department of Social Science, International Pharmaceutical Business School, China Pharmaceutical University, No 639, Longmian Avenue, Jiangning District, Nanjing, China, Tel +8613305151782, Email ghanemikadour@outlook.com

Received: September 25, 2017 | Published: October 24, 2017

could be vulnerable to bankruptcy. After examining the past, the company managers should do a new strategy and plans to shape the future of the company and ensuring its sustained success. Such plans would involve ensuring the qualification and the professionalism of the workers in the company, listening to the customers comments and take their objectives and needs into consideration, be responsible and highly ethical while developing new products and put the costumers benefits as a priority, put a reasonable price for the novel products so that everyone can afford them, always targeting new markets to which entering can be specified in several ways, trying to use the novel technologies and the new techniques in order to maximize the company benefits to its clients and using the sophisticated manners to promote and advertise the new products. ${ }^{4,5}$ Despite the huge efforts and time needed for day-to-day process from the company employees and managers, they should be responsible and have the ethics of the profession, adherence, creativity, discipline, and the spirit of the community to gain a good sustainable future success, recognize trends and constant innovation and competitiveness within the industry.

\section{Acknowledgments}

We acknowledge the Jiangsu Overseas Research \& Training Program for University Prominent Young \& Middle-aged teachers. Kadour Ghanemi is the recipient of a full scholarship from the China Scholarship council.

\section{Conflict of interest}

Author declares that there is no conflict of interest.

\section{References}

1. Stilgoe J, Owen R, Macnaghten P. Developing a framework for responsible Innovation. Research Policy. 2013;42(9):1568-1580.

2. Murphy J, Parry S, Walls J. The EPSRC'S Policy of Responsible Innovation from a Trading Zones Perspective. Minerva; 2016;54(2):151-174. 
3. George Santayana. The Life of Reason: Introduction and Reason in Common Sense. USA: The MIT Press; 1905. p. 1-408.

4. Beqiri G. Innovative Business Models and Crisis Management. Procedia Economics and Finance. 2014;9:361-368.
5. Thorleuchter D, Van Den Poel D. Predicting e-commerce company success by mining the text of its publicly-accessible website. Expert Systems with Applications. 2012;39(17):13026-13034. 